\title{
Women empowerment as an essential tool for national transformation: Niger state, Nigeria experience
}

\author{
A. Isah, L. A. Nafiu* \\ Department of Mathematics/Statistics, Federal University of Technology, Minna, Nigeria
}

Email address:

lanconserv@yahoo.com (L. A. Nafiu)

To cite this article:

A. Isah, L. A. Nafiu. Women Empowerment as an Essential Tool for National Transformation: Niger State, Nigeria Experience, American Journal of Theoretical and Applied Statistics. Vol. 2, No. 2, 2013, pp. 12-14. doi: 10.11648/j.ajtas.20130202.11

\begin{abstract}
Gender statistics is an area that cuts across traditional fields of statistics to identify, produce and disseminate statistics that reflect the realities of the lives of women and men, and policy issues relating to gender. This paper studies women empowerment as a powerful instrument for national transformation and sustained economic growth. Attempt was made at giving the experience of inclusion of women in Niger State, Nigeria in such areas as leadership activity, economic opportunity, political empowerment, educational attainment and health involvement. It is recommended that there should be changes in all sectors to promote gender equality and transform poor rural women into successful business managers.
\end{abstract}

Keywords: Gender, Women, Empowerment, Niger State And Transformation

\section{Introduction}

Women empowerment, often referred to as gender empowerment can be viewed as a phenomenon of giving total official authority or freedom or status that men folks enjoy to women in a manner that safeguard discrimination against them or their under-representation in all sectors of the economy [1]. It is a widely held axiom that what a man can do, a woman can do better. It is on this note, coupled with some women who have stood out and excelled themselves in contributing meaningfully and immensely to the national and global economy, that many countries of the world now adopt different approaches and programmes towards empowering their women. Governments also recognize that women's inclusion drives development and acknowledge that achieving the Millennium Development Goals and national economic and development plans require rapidly moving towards gender equality.

Transformation actually means a complete change from one situation to another, a total departure from the old order to a new one. It does not come accidentally, but require deliberate efforts. To change from a failure to a successful person calls for performance of some activities that will facilitate the actualization of such dreams. In other words, transformation calls for practical actions and goes beyond mere expression or verbal pronouncement, but require a number of tasks to be performed [2].

A society with greater gender equality experience faster economic growth, and benefit from greater agricultural productivity and improved food security. Empowering women to participate in and lead public and private institutions makes these institutions more representative and effective. Increasing girls' and women's education and access to resources improves the health and education of the next generation. Empowering women to participate fully in economic life across all sectors and throughout all levels of economic activity is essential for transformation to:

i. Build strong economies.

ii. Establish more stable and just societies.

iii. Achieve internationally agreed goals for development, sustainability and human rights.

iv. Improve quality of life for women, men, families and communities.

v. Propel businesses' operations and goals.

\section{Literature Review}

Severine and Shahani [2] noted that entire nations, businesses, communities, and groups can benefit from the implementation of programmes and policies that directly adopt the notion of women empowerment. The United Nations General Assembly [3] stressed that the Human Development and Capabilities Approach, The Millennium Development Goals, and other credible approaches/goals point to empowerment and participation as a necessary step if a country is to overcome the obstacles associated with poverty and development. 
Most women across the globe rely on the informal work sector for an income [4]. If women were empowered to do more and be more, the possibility for economic growth becomes apparent. Eliminating a significant part of a nation's work force on the sole basis of gender can have detrimental effects on the economy of that nation [5]. In addition, female participation in counsels, groups, and businesses is seen to increase efficiency [6]. OECD [7] found that, of 500 companies, those with more women board directors had significantly higher financial returns.

UNDP focuses on gender equality and women's empowerment not only as human rights, but also because they are a pathway to achieving the Millennium Development Goals and sustainable development [4]. UNDP coordinates global and national efforts to integrate gender equality and women's empowerment into poverty reduction, democratic governance, crisis prevention and recovery, and environment and sustainable development. In 10 states in India, UNDP joined forces with the ministry for local governance and civil society organizations to support women elected to public office in more than 2,600 village councils. In Ghana, UNDP helped more than 200 rural women to set up six training centres where they learned to produce goods that are now being exported around the world.

South Africa established Gender Policy Framework to ensure that the process of achieving gender equality is at the very centre of the transformation process within all the structures, institutions, policies, procedures, practices and programmes of government, its agencies and parastatals, civil society and the private sector. In Liberia, some noticeable progress towards gender equality has been achieved [8]. The most significant one is the election of President Ellen Johnson Sirleaf as the first female Head of State in Africa.

In Nigeria, though there is nothing in the constitution which excludes the participation of women in politics, yet when it comes to actual practice, there is extensive discrimination [9]. Few and almost insignificant number of women were elected into various posts when the country returned to the democratic rule in the 1999, and in the subsequent 2003, 2007 and 2011 general elections held in the country. Legislative representation has witnessed the presence of women yet they remain under-represented when compared to their male counterparts. Statistics reveal that women only secured 3\% representation in contested positions in $1999,4 \%$ in 2003 , in 2007 they made with only $6 \%$ while that of 2011 was $12 \%$.

\section{Methodology}

Women empowerment programmes can be classified into two broad groups, namely: Economic empowerment of women and Social empowerment of women. The efforts and activities of the Niger State government on these two broad groups to bridge the gender inequality are discussed below.
As part of the efforts of the Executive Governor of Niger State towards gender equality in the State, a one-day National Gender Policy Dialogue programme entitled "Women Empowerment Surest Social Security for Nigeria" was recently held at Minna and it was resolved that strong advocacy must be made for laws that would really protect women and the girl-child because of their vulnerability. It was also stressed that critical success factors to the woman lies in education, equal opportunities and support at all levels and that is the rationale behind giving priority to education in Niger State since education remains the bedrock of the development of any society and the catalyst for the transformation of the State into one of the top three most developed States in Nigeria by the year 2020 (Vision 3-20-20). It is as a result of this that the state now has more women in the state political appointments, with four women members of the Executive Council, four women permanent secretaries, four women Directors-General and numerous women political aides.

The Niger State government has constructed 75 solar-powered and 300 hand pump boreholes, ten Women Development Centres, works training school, Minna and intervened in $51 \mathrm{Bi}$-water schemes to ease water problems in the state as part of the State's Women Empowerment policy.

\section{Economic Empowerment of Women}

In order to economically empower women in Niger State, government came up with microfinance agenda in 2007 by establishing Small and Medium Enterprises (SMEs)/Microfinance Agency in the State. The programme is targeted at the poor and the less privilege especially the youth and women to shift from an idle living to proactive lifestyle [10].

\section{Findings / Policy Implications}

Finding shows that despite government's efforts towards empowering women in the state, the number of women in senior appointments in Niger State's civil service is still very low compared with their men counterpart as given in table 1 . Also, the imbalances in gender education in the State are worse than the average for the North Central Region as given in table 2 .

From the foregoing, it is imperative to note that there has not been enough support for women in Niger State to eliminate all forms of discrimination in politics, economy and education in order to achieve the $30 \%$ representation of women in elective and appointive posts as recommended by the UN Fourth World Conference on Women in 1995 and the Millennium Declaration adopted by 189 countries in 2000 .

\section{Social Empowerment of Women}


Table 1. Number of Women in Senior Appointments in Niger State.

\begin{tabular}{lllllll}
\hline & \multicolumn{2}{c}{$\mathbf{2 0 0 3}$} & \multicolumn{5}{c}{$\mathbf{2 0 0 7}$} & & \\
\cline { 2 - 6 } GL & Male & Female & Male & Female & Male & Female \\
\cline { 2 - 7 } GL 13 & 349 & 87 & 489 & 141 & 663 & 21 \\
GL 14 & 269 & 74 & 553 & 103 & 110 & 91 \\
GL 15 & 89 & 13 & 152 & 22 & 64 & 20 \\
GL 16 & 52 & 2 & 68 & 7 & 24 & 8 \\
GL 17 & 5 & 0 & 9 & 0 & 89 & 26 \\
SG & 73 & 7 & 29 & 5 & 114 & 7 \\
Total & 832 & 183 & 1300 & 278 & 1064 & 173 \\
\hline
\end{tabular}

Table 2. Regional Differences in Overall Literacy Rates.

\begin{tabular}{lllll}
\hline \multicolumn{2}{l}{ Region/States Adult Literacy Rates } & \multicolumn{2}{l}{ Youth Literacy Rate } \\
\hline & Male & Female & Male & Female \\
North Central & 69.0 & 46.1 & 81.6 & 67.1 \\
Benue & 78.0 & 51.1 & 87.6 & 73.5 \\
Kogi & 73.0 & 54.3 & 90.8 & 84.7 \\
Kwara & 66.9 & 44.1 & 84.6 & 70.5 \\
Nassarawa & 65.3 & 35.7 & 73 & 49.2 \\
Niger & 53.7 & 29.0 & 66.2 & 42.7 \\
Plateau & 68.9 & 51.3 & 79.6 & 67.3 \\
FCT & 83.4 & 70.9 & 79.1 & 76.9 \\
\hline
\end{tabular}

\section{Recommendations}

The following recommendations are made to increase the effort in empowering women to transform Niger State in particular and Nigeria as a whole both economically and politically:

(i) Implementation of the provisions of gender policies in the overall interest of the womenfolk.

(ii) Establishment of women's skills centres should be intensified for school dropouts.

(iii) Promotion of girl friendly primary and secondary schools in Niger State.

(iv) Mobilization of parents, communities and relevant agencies to increase access to women education in Niger State.

(v) Loans with low interest rates should be given to women with the hope that they can start a small business and provide for their family.

\section{References}

[1] A. Lopez-Claros, and S. Zahidi, "Women's Empowerment: Measuring the Global Gender Gap." World Economic Forum 91-93 route de la Capite, Cologny/Geneva, 2005.

[2] D. Severine, and L. Shahani, An Introduction to the Human Development and Capability Approach: Freedom and Agency. Sterling, VA: Earthscan, Switzerland, 2009.

[3] U.N., United Nations General Assembly 55th Session. "United Nations Millennium Declaration." Available at www.un.org/millennium/declaration/ares552e.pdf, 2000.

[4] U.N., United Nations Research Institute for Social Development "Combating Poverty and Inequality: Structural Change, Social Policy and Politics. Geneva: UNRISD, 2010 .

[5] UNICEF, Equality in Employment in the State of the World's Children. New York: United Nations Children's Fund, 2007.

[6] B. Argawal, Gender and Green Governance: The Political Economy of Women's Presence Within and Beyond Community Forestry. New York, NY: Oxford University Press, 2010.

[7] OECD, Organisation for Economic Co-operation and Development Annual Report. France: OCED Publications, 2008.

[8] V. Gayflor, and L. Allen, Empowering Women in Liberia. Fact Sheet of Joint Programme on Gender Equality and Women's Empowerment. Liberia: Government of Liberia and the United Nations Publications, 2011.

[9] D. T. Agbalajobi, "Women's participation and the political process in Nigeria: Problems and prospects", African Journal of Political Science and International Relations, vol. 4, pp. 075-082, 2009.

[10] SMEs/Microfinance Agency, The A. B. C. of S.M.E. and Microfinance in Niger State. First Edition, 2007. 